\author{
ANDRZEJ ZAWISTOWSKI \\ Katedra Historii Gospodarczej i Społecznej \\ SGH $w$ Warszawie \\ Biuro Badań Historycznych IPN
}

\title{
„TO NIE WSTYD - BONY, WSTYD TO KOLEJKI”. REGLAMENTACJA CUKRU W PRL W LATACH 1976-1981
}

\begin{abstract}
Abstrakt: W XX w. na ziemiach polskich można wyróżnić cztery okresy reglamentacji artykułów pierwszej potrzeby: 19151921 (czyli okres I wojny światowej i wojny polsko-bolszewickiej), 1939-1949 (okres II wojny światowej i lata powojenne), 19511953 (szczyt stalinizmu) oraz 1976-1989 (czas załamania się gospodarki komunistycznej i lata powszechnego braku towarów w sklepach). Ostatni okres reglamentacji rozpoczęło wprowadzenie w sierpniu $1976 \mathrm{r}$. racjonowania cukru. Władze sięgnęły po to narzędzie w momencie, gdy zostały zmuszone do wycofania się z podwyżki cen, co zaowocowało paniką sklepową. Kartki na cukier wprowadzono, jak zapowiadano, jedynie na okres przejściowy.
\end{abstract}

Słowa kluczowe: reglamentacja, PRL, gospodarka niedoboru, kartki, cukier.
Abstract: The twentieth century witnessed four periods of food rationing in Polish lands: 1915-1921 (First World War and the Polish-Bolshevik War), 1939-1945 (Second World War and post-war years), 1951-1953 (the peak of Stalinism), and 1976-1989 (the breakdown of the communist economy and a long-term general shortage of commodities). The last period of rationing was inaugurated in August 1976 by sugar rations. The authorities resorted to this instrument at a moment when they were compelled to withdraw their price rise policy, which resulted in panic. It was announced that sugar ration cards had been introduced only for a temporary period.

Keywords: rationing, Polish People's Republic, economics of shortage, ration cards, sugar.

„Nie trzeba wielkiej polityki ani wojny, gdyż nawet brak cukru czy mięsa może rozłożyć komunizm od wewnątrz" - taką opinię (przynajmniej według doniesień Służby Bezpieczeństwa) miał latem 1976 r. wyrazić dawny działacz wielkopolskiej endecji ${ }^{1}$. Trudno się z tym nie zgodzić.

${ }^{1}$ AIPN, 0296/101, t. 3, „Informacja o sytuacji społeczno-ekonomicznej w kraju”, 13 VIII 1976, k. 25. 
Ryzykowna i nieodpowiedzialna polityka gospodarcza ekipy Edwarda Gierka doprowadziła do zwiększenia na rynku ilości pieniądza, który nie miał pokrycia w towarze. Spowodowało to tendencje inflacyjne. W Polskiej Rzeczypospolitej Ludowej występowała jej specyficzna forma inflacja tłumiona. Dochody ludności rosły szybciej niż zaopatrzenie rynku. Ludzie posiadający coraz więcej pieniędzy kupowali coraz więcej towarów, obawiając się, iż znikną one ze sklepu. Brak wzrostu cen zachęcał do takiego postępowania. Był to początek procesu, który uruchomił lawinę załamania zaopatrzenia. Rosły też kolejki przed sklepami, a ludzie często kupowali to, co właśnie do sklepu przywieziono. Nie zawsze dany towar był potrzebny kupującemu, ale można było się nim z kimś wymienić na poszukiwany artykuł. Kolejki ustawiały się nie tylko pod sklepami spożywczymi, lecz praktycznie pod wszystkimi placówkami handlowymi (nie wyłączając nawet księgarń czy stacji benzynowych).

Zdając sobie sprawę z samobójczego kursu polskiej gospodarki, w czerwcu 1976 r. władze postanowiły podjąć kroki w celu przywrócenia równowagi rynkowej i, choć w części, dostosować ceny artykułów konsumpcyjnych do faktycznych kosztów produkcji. Oficjalnie projekt operacji związanej z podwyżkami miał zostać przedstawiony przez premiera Piotra Jaroszewicza 24 czerwca 1976 r. na posiedzeniu Sejmu PRL. Przemówienie premiera starannie przygotowywano i wewnętrznie konsultowano. Odnośnie do cen cukru w jego projekcie zapisano: „Inny nieco charakter, aniżeli podwyżka cen mięsa, ma zamierzone podwyższenie cen cukru. Spożycie cukru osiągnęło w Polsce poziom, którego dalszy poważniejszy wzrost nie jest już ani ze względów ekonomicznych, ani dietetycznych uzasadniony. Spożywamy więcej cukru niż w wielu krajach o wyższym niż u nas poziomie rozwoju gospodarczego i standardzie życiowym. [--] Utrzymanie produkcji cukru na poziomie zabezpieczającym potrzeby kraju wymagało tak znacznego podwyższenia cen skupu buraków cukrowych, że deficyt w przemyśle cukrowniczym przekroczył 4 mld złotych. Ceny skupu buraków cukrowych będą musiały ulec jeszcze dalszej podwyżce. W tej sytuacji - zwłaszcza z uwagi na już wysokie spożycie cukru w kraju - nie jest wskazane dalsze utrzymywanie cen cukru na nierentownym poziomie i nie zabezpieczającym pokrycia potrzeb rozwojowych przemysłu cukrowniczego. Doprowadzenie do właściwych warunków ekonomicznych w zakresie produkcji cukru wymaga dosyć znacznej, bo 90 proc. podwyżki jego ceny. Tak więc cena cukru standardowego wzrośnie z 10,50 zł. do 20 zł za kilogram" ${ }^{2}$. Co ciekawe, ostatecznie wygłoszone (a przynajmniej opublikowane) wystąpienie miało zupełnie inną treść.

\footnotetext{
2 AAN, Urząd Rady Ministrów (dalej: URM), 116/3, „Projekt referatu”, k. 81.
} 
„Następna propozycja wynika z potrzeby zrównoważenia stale rosnących kosztów produkcji cukru z koniecznością dalszego podniesienia cen skupu buraków cukrowych oraz rozbudowy i unowocześnienia przemysłu cukrowniczego. Cenę cukru proponujemy więc podnieść do $20 \mathrm{zł} \mathrm{za} 1 \mathrm{~kg}{ }^{\prime 3}$. I to właśnie cena cukru w projekcie władz miała wzrosnąć znacząco - bo o 90 proc. (np. mięsa średnio o 69 proc., choć ceny niektórych wędlin znacznie więcej). Jedynie ryż miał zdrożeć bardziej - bo o 150 proc. $^{4}$

Zapowiedziane podwyżki - nie tylko cukru - spotkały się z protestami społecznymi (największe z nich miały miejsce w Radomiu, Ursusie i Płocku) i zaowocowały decyzją władz o wycofaniu się z planowanych zmian $^{5}$. Po zamieszaniu z wprowadzaniem, a następnie wycofywaniem podwyżki cen artykułów spożywczych społeczeństwo z uwagą obserwowało wypowiedzi Gierka i Jaroszewicza, wyciągając z nich wnioski, że kolejna próba podwyższenia cen jest tylko kwestą czasu ${ }^{6}$ (wszak formalnie początkowo podwyżkę jedynie zawieszono). Nie dziwne więc, że ludzie przypuścili szturm na sklepy, którego nie osłabiły nawet późniejsze uspokajające komunikaty władz. Stefan Kisielewski w dzienniku pod datą 7 sierpnia 1976 r. notował: „Dziwna jest sytuacja, do żarcia nic nie ma, cukier zniknął, inne rzeczy też, przed sklepami ogony, ludzie wściekli"7.

Cukier byłjednym z najbardziej wrażliwych artykułów na rynku. W polskiej tradycji kulinarnej i ekonomicznej (a de facto i politycznej) był wyjątkowym produktem. Przez wiele lat był on (zwłaszcza cukier biały) swoistą oznaką zamożności. Jego pojawianie się na stole, powszechna dostępność (lub znikanie) było często związane z zawirowaniami ekonomicznymi, ale także politycznymi (np. wojna). Jednak cukier w Polsce miał jeszcze inne, swoiste znaczenie: był nieodłącznym składnikiem wielu przetworów, które Polacy masowo w okresie letnio-jesiennym przygotowywali. Dużo cukru pochłaniały też pokarmy przygotowywane dla małych dzieci, zwłaszcza niemowląt. Do tego dochodziły ogromne ilości cukru wykorzystywane podczas świąt $\mathrm{w}$ wypiekach oraz $\mathrm{w}$ procesie bimbrownictwa ${ }^{8}$.

${ }^{3}$ Przemówienie prezesa Rady Ministrów Piotra Jaroszewicza na posiedzeniu Sejmu, „Nowiny. Dziennik Polskiej Zjednoczonej Partii Robotniczej”, 25 VI 1976, s. 3.

4 AAN, URM, 116/3, „Projekt uchwały Rady Ministrów w sprawie regulacji cen i zasad jej rekompensaty (wersja III - 11 VI 1976)", k. 1-2.

${ }^{5}$ Szerzej o źródłach, przebiegu i następstwach kryzysu politycznego w czerwcu 1976 r.: P. Sasanka, Czerwiec 1976. Geneza - przebieg - konsekwencje, Warszawa 2006.

${ }^{6}$ Ibidem, s. 374-375.

7 S. Kisielewski, Dzienniki, Warszawa 2001, s. 874.

${ }^{8}$ Spożycie cukru systematycznie rosło. W 1960 r. statystyczny Polak skonsumował 27,9 kg, w $1970-39,2 \mathrm{~kg}$, a w $1975-43,2 \mathrm{~kg}$. Rocznik Statystyczny 1978, Warszawa 1978, s. 68. Por. też.: AAN, URM, 116/3, „Regulacja cen i zasada jej rekompensaty”, k. 67. 
Towar ten, w odróżnieniu od innych artykułów spożywczych, mógł być także stosunkowo długo przechowywany. W chwilach zagrożenia podwyżką dochodziło więc do działania prostego mechanizmu ekonomicznego: ewentualny wcześniejszy zakup cukru oznaczał - gdy ceny zostaną podniesione - ewidentną oszczędność w domowych finansach. Dlatego też cukier był jednym z towarów, które najczęściej padały ofiarą paniki rynkowej. To przyzwyczajenie Polaków nie zanikło wraz z upadkiem komunizmu, by przypomnieć cukrowe paniki rynkowe wiosną $2004 \mathrm{r}$. (tuż przed przystąpieniem Polski do Unii Europejskiej) oraz w 2011 r. (plotka o tym, że cukier będzie kosztował 7 zł, spowodowała jego masowy wykup i automatyczny wzrost cen o ponad 100 proc.) $)^{9}$.

Latem 1976 r. robotnicy i urzędnicy porzucali swe miejsca pracy, by stanąć w kolejkach po cukier. Bywało, że tłum klientów demolował sklep bądź samowolnie przejmował znajdujący się na zapleczu towar. Jak pisze Paweł Sasanka: „7 lipca 1976 r. w Lublinie w sklepie przy ul. Okrzei kilkusetosobowy tłum złamał jednemu z kolejkowiczów nogę, a personel innego został obrzucony butelkami. W sklepie WSS [Warszawska Spółdzielnia Spożywców] nr 198 w Bydgoszczy tłum liczący około 500 osób połamał ladę sklepową. 8 lipca w Rzeszowie, w sklepie obleganym przez kilkuset kupujących wybito szyby, w związku z czym interweniowała milicja. W pięciu sklepach na terenie Trójmiasta w kolejkach wybierano komitety społeczne, czuwające nad sprzedażą całego dostarczonego do sklepu cukru. 9 lipca w sklepie WSS przy ul. Jadźwingów w Warszawie kilkusetosobowy tłum wdarł się na zaplecze i - jak informowano w meldunku - «stosując groźbę zdemolowania pomieszczeń i pobicia personelu, zmusił do sprzedaży całotygodniowej normy cukru»”; „w Nowej Wsi w gminie Sępolno stojące w kolejce kobiety wdarły się do sklepu, z którego zabrały 20 kg cukru i rozdzieliły go między siebie, pozostawiając należność. W dwóch sklepach w województwie koszalińskim klienci przedarli się na zaplecze, aby upewnić się, czy rzeczywiście cukru nie ma. «Personel sklepów niejednokrotnie zwraca się do terenowych jednostek MO [Milicji Obywatelskiej] z prośbą o interwencję, gdyż oczekujący klienci okupują sklepy, grożąc ich zniszczeniem, wdzierając się na zaplecza sklepów. Mają miejsce pobicia sprzedawców (woj. skierniewickie, konińskie)» - głosił raport MSW"10. Rosły nieprawidłowości w obrębie dostaw i sprzedaży. Konwojenci i sprzedawcy starali się „uszczuplić” dostawy, sprzedając pozyskany cukier poza oficjalnym obrotem. Zdarzało się, że do sklepów - dzięki operatywności osób odpowiedzialnych za

\footnotetext{
${ }^{9}$ Por. np. Cukier drożeje, klienci wykupuja wszystko, www.jarocinska.pl (1 III 2011).

10 P. Sasanka, op. cit., s. 376, 382.
} 
dostawę - zamiast cukru trafiała jedynie ekwiwalentna kwota pieniędzy. W Świdwinie SB zanotowała powtarzającą się opinię „cukier będzie dopiero, jak podrożeje"11. Z niepokojem władze odnotowywały fakt wspomnianego powyżej samoistnego wyłaniania się komitetów kolejkowych kontrolujących poziom dostaw cukru do sklepu ${ }^{12}$. Było to ewidentne naruszenie zasad systemu politycznego PRL.

Jaroszewicz na posiedzeniu rządu 13 lipca 1976 r. mówił: „Oczywiście całemu temu procesowi, który zaszedł po 24 czerwca, towarzyszyło wiele ujemnych i nadal towarzyszy dotąd jeszcze wiele ujemnych zjawisk. Jednym z tych zjawisk jest niepokój na rynku, który znalazł swój najjaskrawszy wyraz na odcinku cukru"13.

Napór klientów na sklepy spowodował, że kierownicy sklepów zaczęli masowo wnioskować o zwiększanie dostaw. 2 lipca 1976 r. w magazynach w Warszawie w końcu dnia znajdował się zapas jedynie na dwa kolejne dni ${ }^{14}$. Jeszcze mniejsze - bo poniżej dziennej normy - były zapasy w hurtowniach WSS „Społem” w Bydgoszczy, Toruniu, Włocławku, Jeleniej Górze, Wrocławiu, Wałbrzychu i Olsztynie. Lepsza sytuacja była w sieci handlowej podległej Wojewódzkim Związkom Gminnych Spółdzielni „Samopomoc Chłopska” - w sklepach wiejskich na początku lipca sytuacja wydawała się opanowana ${ }^{15}$.

Niemal natychmiast pojawiła się reglamentacja żywiołowa, czyli ograniczanie jednorazowej ilości sprzedaży towarów. Próbowano limitować dostawy z hurtowni, a przede wszystkim ograniczać możliwość zakupu przez klientów indywidualnych. Na początku lipca 1976 r. kontrolerzy Państwowej Inspekcji Handlowej raportowali: „Kierownicy sklepów nie wywierają nacisków na zwiększenie dostaw przez hurt z uwagi na wprowadzenie limitowanych dostaw. Jednorazowa sprzedaż cukru dla nabywców jest regulowana przez handel w granicach 1-5 kg w zależności od sytuacji w zaopatrzeniu danego terenu"16.

11 AIPN w Szczecinie (dalej: AIPN Sz), 443/50, „Telefonogram z Komendy Miejskiej MO w Szczecinku do Komendy Wojewódzkiej MO w Koszalinie", 5 VII 1976, k. 199.

12 AIPN, 0296/101, t. 3, „Biuro do walki z Przestępstwami Gospodarczymi KG MO, Informacja o bieżącej sytuacji w zaopatrzeniu rynku w niektóre artykuły żywnościowe", 10 VII 1976, k. 113-114.

13 AAN, URM, 94/63, „Stenogram posiedzenia Rady Ministrów w dniu 13 lipca 1976 r.", k. 213.

14 AAN, Państwowa Inspekcja Handlowa (dalej: PIH), 1/15, „Informacja w sprawie realizacji limitowania dostaw z hurtu do detalu na terenie m. st. Warszawy", k. 144.

15 AAN, PIH, 1/15, „Informacja Państwowej Inspekcji Handlowej w sprawie limitowania dostaw cukru z hurtu do detalu", 3 (?) VII 1976, k. 146-148.

${ }^{16}$ AAN, PIH, 1/15, „Informacja Państwowej Inspekcji Handlowej”, 5 VII 1976, k. 141. 
Podjęte działania były zgodne z przygotowanymi wcześniej na potrzeby czerwcowej podwyżki wytycznymi dla handlu i gastronomii. Szturm na sklepy był bowiem do przewidzenia. Normatywy przewidywały wzmożoną kontrolę zakupu towarów, ograniczając taką możliwość do ilości „bieżąco zaspokajających normalne potrzeby”" . Oczywiście była to norma nieostra, więc zdecydowano się na literalne wyszczególnienie owych „normalnych potrzeb”. Przewidziano następujące normy: np. cukier $-1 \mathrm{~kg}$, wędlina $-0,5 \mathrm{~kg}$, mięso i drób $-1 \mathrm{~kg}$, kasza -1 opakowanie, masło $-0,25 \mathrm{~kg}$, jaja -10 sztuk, ziemniaki $-5 \mathrm{~kg}^{18}$. Ograniczenie dotyczyło także planu dziennej sprzedaży - 40 proc. dostawy sprzedawano rano, a pozostałą część po południu ${ }^{19}$. Częściowo niwelowano w ten sposób opuszczenia przez pracowników zakładów pracy w celu zakupu towaru, który po zakończeniu dniówki byłby niedostępny.

Kierownicy sklepów zostali zobowiązani do udzielania klientom wyczerpujących informacji i dbałości o proporcjonalny podział zmagazynowanego towaru na wszystkie dni funkcjonowania sklepu (aż do kolejnej dostawy). Towary cieszące się szczególną popularnością miały trafiać ze stoisk samoobsługowych do sprzedaży przez personel. Obsługa sklepów - w uzasadnionych przypadkach - miała wspomagać się „,czynnikiem społecznym": samorządem mieszkańców, członkami zarządów spółdzielni itp. Oczywiście regulacje te (zwłaszcza normy „normalnych potrzeb") skierowane były jedynie do wiadomości obsługi sklepów ${ }^{20}$.

Sprzedaż cukru ograniczano także, przenosząc ją do zakładów pracy, sprzedając go na podstawie list imiennych lub w wybranych - kontrolowanych i ochranianych - sklepach ${ }^{21}$. Była to nie tylko próba ratowania

17 AIPN, 0753/35, „Lato-76, Wytyczne Ministra Handlu Wewnętrznego i Usług w sprawie ograniczeń w sprzedaży artykułów żywnościowych w placówkach detalicznych uspołecznionych przedsiębiorstw handlowych w okresie konsultacji zmiany cen (materiał dla organów administracji terenowej, wojewódzkich organizacji handlowych i kierowników sklepów detalicznych)", k. 23-24.

18 AIPN, 0753/35, „Lato-76, Wykaz przykładowej ilości wybranych artykułów żywnościowych, bieżąco zaspokajających normalne potrzeby nabywcy kupowanych w punktach sprzedaży detalicznej, załącznik do: Wytyczne Ministra Handlu Wewnętrznego i Usług w sprawie ograniczeń w sprzedaży artykułów żywnościowych w placówkach detalicznych uspołecznionych przedsiębiorstw handlowych w okresie konsultacji zmiany cen (materiał dla organów administracji terenowej, wojewódzkich organizacji handlowych i kierowników sklepów detalicznych)", k. 24-25.

19 AIPN, 0296/101, t. 3, „Biuro do walki z Przestepstwami Gospodarczymi KG MO, Informacja o bieżącej sytuacji w zaopatrzeniu rynku w niektóre artykuły żywnościowe", 10 VII 1976, k. 113.

20 AIPN, 0753/35, „Lato-76, Wytyczne Ministra Handlu Wewnętrznego i Usług w sprawie ograniczeń w sprzedaży artykułów żywnościowych”, k. 23-24.

${ }^{21}$ AIPN, MSW II, 96/264, „Informacja o orzecznictwie kolegiów do spraw wykroczeń w sprawach o wykroczenia przeciwko interesom konsumentów", 18 VIII 1976, k. 53-54; 
nabrzmiałej konfliktem sytuacji, ale też swoista samoobrona personelu sklepowego przed grożącym jej linczem.

Pierwsza dekada lipca 1976 r. przyniosła blisko 200-proc. wzrost sprzedaży podstawowych artykułów spożywczych. Cena cukru na czarnym rynku poszybowała natychmiast do góry, przewyższając poziom detaliczny o ponad 100 proc. ${ }^{22} \mathrm{~W}$ sposób drastyczny zmniejszały się zapasy cukru. $\mathrm{O}$ ile sprzedaż w przedsiębiorstwach oraz wydzielonych sklepach w zasadzie spełniła pokładane w tym rozwiązaniu nadzieje, to wprowadzona miesięczna i dobowa reglamentacja już nie: „niektórzy słabsi wojewodowie, słabsze kierownictwo wojewódzkie złamało zasady reglamentacji, sprzedały za wiele, chociaż wiadomo było, że nawet zwiększenie o 30 proc. sprzedaży cukru prowadzi tylko do jego wyłapania przez spekulantów, a nie rozwiązuje problemu zaopatrzenia rodzin"23.

Zaistniała sytuacja była nie do zaakceptowania nie tylko ze względów gospodarczych i społecznych, ale też politycznych. Funkcjonariusze MO z województwa poznańskiego donosili: „Przed sklepami spożywczymi i mięsnymi tworzą się długie kolejki osób wyczekujących na dostawy cukru. W związku z tym, że niekiedy oczekiwanie na dostawę od wielu godzin nie pozwala uzyskać cukru wszystkim chętnym, wywołuje to oburzenie ludności i nieprzychylne dla polityki naszej partii i rządu komentarze"24. W planie działań Komendy Wojewódzkiej MO w Gdańsku na 12 sierpnia 1976 r. zapisano: „Nasilającym się w ostatnich tygodniach trudnościom rynkowym w zakresie zaopatrzenia sklepów w dostosowane do popytu ilości cukru towarzyszył wzrost nastrojów niezadowolenia [we] wszystkich kontrolowanych środowiskach i obiektach. W pojedynczych przypadkach znalazło to swój wyraz we wrogich komentarzach pod adresem władz, a także czynnych napaściach na personel sklepów w celu wyegzekwowania tą drogą towaru. [--] Mimo iż nie odnotowaliśmy na naszym terenie ostrzejszych masowych form wystąpień, istniało stałe zagrożenie wzmożenia się sytuacji konfliktowej"25. Jak czytamy w raporcie MSW, „Notowano znaczne nasilenie komentarzy stwierdzających, że

AAN, URM, 94/63, „Stenogram posiedzenia Rady Ministrów w dniu 13 lipca 1976 r.”, k. 213; P. Sasanka, op. cit., s. 375-376, 382-385.

22 P. Sasanka, op. cit., s. 373-374, 381-385.

23 AAN, URM, 94/63, „Stenogram posiedzenia Rady Ministrów w dniu 13 lipca 1976 r.", k. 213.

${ }^{24}$ AIPN w Poznaniu (dalej: AIPN Po), 06/161/2, „Informacje źródłowe, Informacja o sytuacji rynkowej w województwie poznańskim", 12 VIII 1976, k. 3-4.

${ }^{25}$ AIPN w Gdańsku, 0046/349/7/DVD, „Plan działań wzmożonego rozpoznania sytuacji operacyjno-politycznej i nastrojów kontrolowanych przez Wydział III KW MO [w] obiektach i środowiskach województwa gdańskiego po ogłoszeniu decyzji Rządu PRL z dnia 12 sierpnia 1976 r. o racjonalizowanej [sic!] sprzedaży cukru", 12 VIII 1976, k. 246. 
władze celowo wywołują trudności rynkowe m.in. poprzez ograniczanie dostaw cukru, aby zmęczyć społeczeństwo i łatwiej uzasadnić podwyżkę cen. Zarzuty takie podnosili m.in. pracownicy FSO Żerań, Jelczańskich Zakładów Samochodowych oraz górnicy ZG «Polkowice»"26.

Czy przygotowując podwyżki cen, władze nie zdawały sobie sprawy z możliwości takich konsekwencji? Oczywiście tak (świadczą o tym chociażby wspomniane powyżej instrukcje dla pracowników handlu), choć ich skala zdecydowanie przewyższyła przewidywania. W czerwcu 1976 r. w planach operacji Lato-76 zaplanowano dosyć szczegółowe monitorowanie przez SB i MO nastrojów, komentarzy i możliwych zagrożeń „popodwyżkowych”. „Biuro d/w z Przestępstwami Gospodarczymi KG MO [Komendy Głównej MO] i jego jednostki terenowe zapewnią dopływ informacji o wszelkiego rodzaju zakłóceniach na rynku wewnętrznym, głównie o nierytmicznych dostawach towarów do sklepów handlu detalicznego, masowym wykupowaniu artykułów codziennego użytku, spekulacji towarami rynkowymi"27. Służby podległe MSW (także Dowództwo Wojsk Ochrony Pogranicza i Komendy Głównej Straży Pożarnych) zostały zobowiązane do natychmiastowego raportowania powstania tego typu zjawisk ${ }^{28}$. Przygotowywano się do interwencji lokalnych, które miały niwelować zagrożenia.

Zamieszanie z odwołaniem podwyżki i skala zjawisk negatywnych w sposób oczywisty przerosła zaplanowane działania. Zaczęto więc szukać winnych. Na posiedzeniu rządu premier nawoływał: „Trzeba karać surowo tych [--], którzy zajęli się spekulacją, a mamy już kilkadziesiąt, to tow. [Mirosław] Milewski potwierdzi, ewidentnych spraw spekulacji tona cukru, pół tony cukru, ćwierć tony cukry, worek cukru, ot takie sprawy mamy już ewidentne. To są różni ludzie i konwojenci, i sprzedawcy, i całe sklepy z całego aparatu sklepów i różne sprawy"29. 14 lipca minister spraw wewnętrznych Stanisław Kowalczyk wydał więc zarządzenie nakazujące wzmocnienie działań antyspekulacyjnych i przyśpieszenie procedur postępowań w tych sprawach. „W ostatnim okresie na terenie kraju stwierdzono wzmożony wykup, w nadmiarze bez uzasadnionych przyczyn artykułów żywnościowych. Zjawisko to powoduje zakłócenia

${ }^{26}$ AIPN, 0296/101, t. 3, „Informacja o sytuacji społeczno-ekonomicznej w kraju”, 13 VIII 1976, k. 23.

27 AIPN, 0753/35, „Lato-76, Program ćwiczeń «Lato-76». Załącznik do Zarządzenia nr 040/76 Ministra Spraw Wewnętrznych z dnia 10 czerwca 1976 r.”, k. 21.

${ }_{28}$ AIPN, 0753/35, „Lato-76, Wytyczne Kierownika Sztabu MSW do nadsyłania informacji przez jednostki organizacyjne resortu spraw wewnętrznych w okresie ćwiczeń «Lato-76»", k. 33-35.

${ }^{29}$ AAN, URM, 94/63, „Stenogram posiedzenia Rady Ministrów w dniu 13 lipca 1976 r.", k. 223. 
w dystrybucji i zaopatrzeniu ludności oraz stwarza warunki do spekulacji tymi towarami"30. Teleks podobnej treści wysłał do podwładnych prokurator generalny PRL Lucjan Czubiński ${ }^{31}$. Kontrole PIH wskazywały na nasilający się proceder sprzedawania towarów przez konwojentów lub sprzedawców od strony zaplecza ${ }^{32}$. Rozpoczęło się polowanie na spekulantów. Pomiędzy 15 lipca a 15 sierpnia do kolegiów do spraw wykroczeń wpłynęło 578 wniosków o ich ukaranie. Spośród rozpoznanych spraw znacząca większość dotyczyła nieuczciwych pracowników handlu ${ }^{33}$.

Spekulacja nie była jednak podstawową bolączką handlu. Towaru wciąż brakowało, a rynek wydawał się nienasycony. Mimo podejmowanych działań sytuacja nie wydawała się polepszać. 12 sierpnia - a więc po przeszło miesiącu od rozpoczęcia szturmu na sklepy - wicepremier Tadeusz Pyka na posiedzeniu rządu referował: „Analiza pokazała, iż gdyby dostarczyć ilość cukru ponad planowane ilości na miesiąc lipiec i sierpień o 100 proc., i tak zaspokojenie nie byłoby pewne. [--] Tworzą się duże kolejki. Kolejki są coraz bardziej agresywne, powstaje bardzo niekorzystna i niesprzyjająca sytuacja, cukier wykupują jedni i ci sami, zaś kontrole pokazują, iż w niektórych mieszkaniach ilość cukru waha się od 30 do $1600 \mathrm{~kg}$. Są ludzie, którzy mają cukier w wielu workach dlatego, iż liczą na to, jeśli kiedyś będzie podwyżka cen to i tak na tym zyskają. Zaczął się rynek spekulacyjny. Aktualne ceny czarnorynkowego cukru wahają się od 30 do 50 zł z kilogram. Sprzedają również cukier w szklankach, która posiada ileś tam gram i szklanka kosztuje 10 zł"34.

Próbując walczyć z brakiem cukru na rynku - władze 11 sierpnia 1976 r. wprowadziły reglamentowaną sprzedaż cukru na podstawie specjalnych „biletów towarowych” oraz równolegle po cenach komercyjnych $^{35}$. Formalnie zapowiedziano to rozwiązanie jedynie na okres przejściowy do 15 września 1976 r. Nie były to deklaracje prawdziwe. Już w połowie lipca Jaroszewicz mówił, że naruszenie zapasów podczas

30 AIPN, 0753/35, „Lato-76, Zarządzenie nr 53/76 Ministra Spraw Wewnętrznych z dnia 14 lipca 1976 r.”, k. 359.

31 AIPN, MSW, 96 264, „Telex do wszystkich prokuratorów wojewódzkich”, 14 VIII 1976, k. 59-60.

${ }^{32}$ AAN, PIH, 1/15, „Informacja Państwowej Inspekcji Handlowej o wynikach kontroli przeprowadzonych w celu przeciwdziałania nielegalnej sprzedaży artykułów żywnościowych", 17 (?) VII 1976, k. 152-156.

33 P. Sasanka, op. cit., s. 373-374, 381-385.

34 AAN, URM, 5.3/91, „Zapis przebiegu obrad posiedzenia Rady Ministrów w dniu 12 sierpnia 1976 r.", k. 256.

35 Osoby posiadające „bilety towarowe” otrzymały prawo do zakupu określonej ilości cukru po dotychczasowych cenach (10,50 zł za kg), pozostała część cukru była dostępna w sprzedaży w po tzw. cenach komercyjnych (26 zł za kg). 
paniki rynkowej spowodowało, że tylko minimalne spożycie cukru pozwoli dotrwać do okresu, gdy do sklepów trafi produkcja z jesiennych zbiorów ${ }^{36}$. Jasne było więc, że „kartkowy” pomysł miał trwać dłużej niż tylko cztery tygodnie. „Rzecz jasna nie potrafimy jednak określić już dzisiaj terminu zrezygnowania $\mathrm{z}$ tego systemu"37. Także społeczeństwo w deklarację krótkotrwałej reglamentacji zbytnio nie wierzyło ${ }^{38}$.

W rzeczywistości decyzję o wprowadzeniu kartek na cukier podjęto jeszcze w lipcu $1976 \mathrm{r} .{ }^{39}$ Nie była ona jednak możliwa do natychmiastowej realizacji. Co prawda istniał zbudowany dokładnie 15 lat wcześniej system reglamentacji, nie został on jednak uruchomiony ${ }^{40}$. Na wprowadzonych w sierpniu 1976 r. „biletach towarowych” widnieje data 25 lipca 1976 r. To dokładnie dzień później niż wydane przez Dyrektora Biura Operacyjnego KG MO polecenie przeglądu dokumentów dotyczących reglamentacji znajdujących się od 1961 r. w depozycie milicyjnym $^{41}$. Być może wówczas okazało się, że przygotowany system nie jest adekwatny do wprowadzonego rok wcześniej podziału administracyjnego Polski na 49 województw ${ }^{42}$. Znacznie prościej było wydrukować nowe

${ }^{36}$ AAN, URM, 94/63, „Stenogram posiedzenia Rady Ministrów w dniu 13 lipca 1976 r.", k. 214.

37 AAN, Komitet Centralny Polskiej Zjednoczonej Partii Robotniczej (dalej: KC PZPR), XI 190, „Tekst wystąpienia członka Biura Politycznego, Sekretarza KC towarzysza Edwarda Babiucha na telekonferencji z I sekretarzami komitetów wojewódzkich w dniu 11 sierpnia 1978 r.", k. 8.

${ }^{38}$ AIPN, 0296/101, t. 3, „Informacja o sytuacji społeczno-ekonomicznej w kraju w dniach 14-15 bm.", 16 VIII 1976, k. 33-34.

${ }^{39}$ AAN, URM, 5.3/91, „Zapis przebiegu obrad posiedzenia Rady Ministrów w dniu 12 sierpnia 1976 r.”, k. 263.

${ }^{40} \mathrm{~W}$ sierpniu $1961 \mathrm{r}$. w momencie budowy muru berlińskiego przygotowano cały system reglamentacji, a nawet wydrukowano tzw. ślepe kartki i rozwieziono je do komend wojewódzkich MO w cały kraju. System był gotowy na początku września $1961 \mathrm{r}$. Jednak napięcie związane z kryzysem berlińskim opadało i operacja przestała być potrzebna. System jednak zachowano. AAN, URM, 218/51, „Uchwała nr 312 Komitetu Ekonomicznego Rady Ministrów z dnia 12 sierpnia 1961 r. w sprawie zasad sprzedaży towarów w uspołecznionych przedsiębiorstwach handlu detalicznego w przypadkach nadmiernego wykupu artykułów codziennego użytku”, k. 54; AAN, URM, 62/27, „Uchwała nr 312 Komitetu Ekonomicznego Rady Ministrów z dnia 12 sierpnia 1961 r. w sprawie zasad sprzedaży towarów w uspołecznionych przedsiębiorstwach handlu detalicznego w przypadkach nadmiernego wykupu artykułów codziennego użytku", k. 2. Szerzej: A. Zawistowski, Kartki na wojnę, której nie było. Planowany mechanizm reglamentacji artykułów pierwszego zapotrzebowania w PRL w wypadku sytuacji nadzwyczajnej, DN 48, 2016, 1, s. 67-82.

${ }^{41}$ AIPN, 00133/203, „Komenda Wojewódzka MO w Kielcach, Protokół komisyjnego zniszczenia materiałów Ministerstwa Handlu Wewnętrznego Wydział Wojskowy, zdeponowanych w Komendzie Wojewódzkiej MO w Kielcach (11 października 1982 r.)”, k. 29.

${ }^{42}$ Gdy w 1975 r. przeprowadzono w PRL reformę administracyjną, w ramach której 
„bilety towarowe”, choć trwało to kolejne trzy tygodnie. Przygotowania te nie uszły jednak uwadze społeczeństwa ${ }^{43}$.

Biuro Polityczne KC PZPR decyzję o wprowadzeniu reglamentacji formalnie podjęło 11 sierpnia $1976 \mathrm{r}$. Tego samego dnia o wprowadzeniu kartek na cukier Edward Babiuch poinformował I sekretarzy komitetów wojewódzkich PZPR. „Od pewnego czasu szereg komitetów wojewódzkich przekazuje nam postulaty aktywu, organizacji partyjnych, kolektywów robotniczych, by sytuację tę przerwać poprzez podwyższenie cen cukru bądź wprowadzenie bonów gwarantujących każdemu człowiekowi pracy i jego rodzinie cukier w ilościach zaspokajających bieżące potrzeby spożywcze. Szereg komitetów wojewódzkich i urzędów wojewódzkich wprowadziło zgodnie z tymi postulatami sprzedaż cukru poprzez zakłady pracy lub sprzedaż na listy"44. Babiuch odrzucał możliwość podniesienia ceny, gdyż - jak twierdził - byłoby to sprzeczne z decyzjami z dnia 13 lipca 1976 r. o wycofaniu się z podwyżek. Dlatego zdecydowano się na wprowadzenie kartek ${ }^{45}$. Sekretarz KC prosił o pomoc i wyjaśnianie ludziom powodów tej decyzji: ,jest to decyzja wymuszona przez sytuację, że sytuację tę wywołali ludzie kierujący się egoistycznymi pobudkami, że jest to decyzja podjęta dla ochrony potrzeb i interesów ludzi pracy i ich rodzin. Główny i jedyny cel tej operacji polega na tym, by zagwarantować każdemu człowiekowi pracy i jego rodzinie ilość cukru niezbędną dla zaspokojenia bieżących potrzeb bez tracenia czasu w kolejkach i niepotrzebnego denerwowania się. To jest istota sprawy. Cena komercyjna ma w tej koncepcji znaczenie drugorzędne. Przecież normalnie

powstało 49 województw, Ministerstwo Handlu Wewnętrznego i Usług rozpoczęło proces dyslokacji depozytów do nowych jednostek organizacyjnych MO. Operacja ta zakończyła się fiaskiem, gdyż - jak raportowali milicjanci - ministerstwo nie było w stanie podać precyzyjnych danych demograficznych, umożliwiających odpowiedni podział kartek, AIPN, 00133/203, „Notatka służbowa dotycząca dotychczasowej realizacji operacji «Niepogoda» $\mathrm{i}$ «Wicher» przygotowana przez naczelnika wydziału I Biura Operacyjnego KG MO ppłk. J. Łucka", k. 5.

${ }^{43}$ Ponad dwutygodniowa różnica pomiędzy datą emisyjną umieszczoną na kartkach a ogłoszoną decyzją o reglamentacji cukru po raz kolejny zachwiała zaufaniem do władz. „Komentarze osób odbierających bilety powoduje umieszczona na nich data wydrukowania «25 lipca 1976», która podważa wypowiedzi o tym, że decyzja w tej sprawie wydana została dopiero w sierpniu" - notował zastępca naczelnika wydziału do walki z przestępstwami gospodarczymi KW MO w Poznaniu. AIPN Po, 06/161/2, „Informacje źródłowe, Informacja o sytuacji rynkowej w woj. poznańskim”, 14 VIII 1976, k. 44.

${ }^{44}$ AIPN, 0296/101, t. 3, „Informacja o sytuacji społeczno-ekonomicznej w kraju w dniach 14-15 bm.", 16 VIII 1976, k. 1.

${ }^{45}$ AAN, KC PZPR, XI 190, „Tekst wystąpienia członka Biura Politycznego, Sekretarza KC towarzysza Edwarda Babiucha na telekonferencji z I sekretarzami komitetów wojewódzkich w dniu 11 sierpnia 1978 r.”, k. 1-8. 
olbrzymia większość ludzi pracy korzystać z niej nie będzie, gdyż ilość cukru zagwarantowana biletami jest wystarczająca. Cena komercyjna jest jednak niezbędna, ponieważ wśród obywateli naszego kraju są również ludzie nigdzie nie pracujący, bez stałego źródła utrzymania, są także rolnicy posiadający indywidualne gospodarstwa rolne nic państwu nie sprzedający, sprzedający całą swoją produkcję na wolny rynek, których to kategorii nie obejmujemy bonami. Są w naszym kraju turyści zagraniczni, którzy także nie dostaną bonów oraz znajdą się zapewne tacy, którzy zechcą z różnych powodów cukru więcej, niż jest to niezbędne do codziennych potrzeb. Ci wszyscy, jeśli nie ustalimy ceny komercyjnej, musieliby kupować u paskarzy. Niemożliwość legalnego kupowania cukru poza bonami stworzyłaby czarny rynek z paskarskimi cenami" 46 .

Członkowie Rady Ministrów zostali o wprowadzeniu kartek formalnie powiadomieni 12 sierpnia $1976 \mathrm{r}^{47}$ Decyzja ta - co zrozumiałe nie wywołała już dużego poruszenia (prasa donosiła o niej już rano), a dyskusja toczyła się przede wszystkim wokół doprecyzowania grup, którym kartki na cukier byłby przynależne. Jedynie na marginesie Pyka poinformował, że rozważano inną decyzję - podwyżkę cen. Uznano jednak, że w sytuacji na rynku wewnętrznym wycofanie się z deklaracji, iż w 1976 r. takich podwyżek nie będzie, jest niewskazane. Problemem było też odpowiednie wyznaczenie ceny ${ }^{48}$.

Formalnie decyzja o rozpoczęciu reglamentowanej sprzedaży cukru została wprowadzona uchwałą Rady Ministrów wydaną 12 sierpnia 1976 r. ${ }^{49}$ Jej preambuła głosiła: „W celu zapewnienia normalnego i sprawiedliwego zaopatrzenia w cukier wszystkich ludzi pracy i ich rodzin oraz przeciwdziałania spekulacji cukrem Rada Ministrów uchwala, co następuje" ${ }^{50}$. Tego samego dnia odpowiednie zarządzenie wydał minister handlu wewnętrznego i usług ${ }^{51}$. Jak już wzmiankowano, kartki miały być wydane na okres 15 sierpnia - 15 września $1976 \mathrm{r}^{52}$

46 Ibidem, k. 3.

47 AAN, URM, 5.3/91, „Zapis przebiegu obrad posiedzenia Rady Ministrów w dniu 12 sierpnia 1976 r.", k. 256-257.

48 Ibidem, k. 262.

${ }^{49}$ AAN, URM, 94/73, „Uchwała nr 174 RM w sprawie wprowadzenia na okres przejściowy sprzedaży cukru na bilety towarowe oraz sprzedaży komercyjnej cukru", k. 446.

${ }^{50}$ Ibidem.

51 AAN, Ministerstwo Handlu Wewnętrznego i Usług (dalej: MHWiU), 20/4, t. 3, „Zarządzenie nr 95 Ministra Handlu Wewnętrznego i Usług z dnia 12 sierpnia 1976 r. w sprawie wprowadzenia na okres przejściowy sprzedaży cukru na podstawie biletów towarowych", k. 175-178.

52 AIPN, 0753/35, Lato-76, Stenogram z telekonferencji wiceministra gen. Bogusława Stachury, 11 VIII 1976, k. 134. 
Tak jak wspomniano powyżej, osoby posiadające „bilety towarowe” otrzymały prawo do zakupu określonej ilości cukru po dotychczasowych cenach (10,50 zł za kg), pozostała część cukru była dostępna w sprzedaży w po tzw. cenach komercyjnych ( 26 zł za kg) ${ }^{53}$. Większość społeczeństwa (w tym część rolników, którzy sprzedawali państwu swoją produkcję, a także współmałżonkowie) otrzymała miesięczny przydział w wysokości 2 kg cukru. Rolnikom dostarczającym do państwowych punktów skupu niewielkie ilości (oraz członkom rodzin wszystkich mieszkańców wsi powyżej 14 roku życia) przysługiwał 1 kg tańszego cukru. Rolnicy nie kontraktujący byli z systemu wyłączeni ${ }^{54}$. Dzieci do lat 14 otrzymywały przydział dwukilogramowy. Rolnicy renciści mieli do dyspozycji 1,5 kg kartkowego cukru ${ }^{55}$.

Zakłady gastronomiczne, stołówki przyzakładowe, zakłady przetwórstwa (drobne uspołecznione i nieuspołecznione) oraz „inni uprawnieni odbiorcy" mogli kupować cukier po cenach niższych na podstawie zamówień, pozostali odbiorcy pozarynkowi - po cenach komercyjnych ${ }^{56}$.

Zaproponowana cena komercyjna była niższa, niż zakładano jeszcze dzień przed ogłoszeniem decyzji. Wiceminister MSW Bogusław Stachura podczas telekonferencji z podległymi służbami jeszcze dzień wcześniej informował, że cena komercyjna będzie wynosiła $30 \mathrm{zł}^{57}$. Wieczorem 11 sierpnia zdecydowano o jej obniżeniu ${ }^{58}$.

${ }^{53}$ Czyli nowa cena była o 6 zł wyższa, niż pierwotnie planowano i aż o ok. 150 proc. wyższa niż cena sprzed podwyżki.

${ }^{54}$ Początkowo wszyscy rolnicy mieli dostać $1,5 \mathrm{~kg}$, a ich dzieci do 14 roku życia $2 \mathrm{~kg}$. „Zaoszczędzony” na rolnikach cukier miał zapewnić ciągłość sprzedaży komercyjnej. „Poza tym inne są jednak warunki i możliwości zaopatrzenia w artykuły żywnościowe górników, hutników, stoczniowców, w ogóle robotników w przemyśle, a inne są możliwości zaopatrzenia w artykuły stanowiące substytut cukru na wsi" (AAN, KC PZPR, XI 190, „Tekst wystąpienia członka Biura Politycznego, Sekretarza KC towarzysza Edwarda Babiucha na telekonferencji z I sekretarzami komitetów wojewódzkich w dniu 11 sierpnia 1978 r.”, k. 6-7); „Polityka ta ma więc na celu umacnianie troski o rolników kontraktujących i sprzedających swoje produkty państwu” (AIPN, 0753/35, „Lato-76, Stenogram z telekonferencji wiceministra gen. Bogusława Stachury”, 11 VIII 1976, k. 134).

55 AAN, URM, 94/73, „Uchwała nr 174 RM w sprawie wprowadzenia na okres przejściowy sprzedaży cukru na bilety towarowe oraz sprzedaży komercyjnej cukru", k. 446-448.

${ }^{56}$ AAN, MHWiU, 20/4, t. 3, „Zarządzenie nr 95 Ministra Handlu Wewnętrznego i Usług z dnia 12 sierpnia 1976 r. w sprawie wprowadzenia na okres przejściowy sprzedaży cukru na podstawie biletów towarowych”, k. 175-178.

${ }^{57}$ AIPN, 0753/35, „Lato-76, Stenogram z telekonferencji wiceministra gen. Bogusława Stachury", 11 VIII 1976, k. 134.

58 AAN, KC PZPR, XI 190, „Tekst wystąpienia członka Biura Politycznego, Sekretarza KC towarzysza Edwarda Babiucha na telekonferencji z I sekretarzami komitetów wojewódzkich w dniu 11 sierpnia 1978 r.”, k. 8. 
Decyzję, jak już to zostało zaznaczone powyżej, podjęto 11 sierpnia, a poinformowano o niej publicznie dzień później. 12 sierpnia rano w prasie pojawił się skrócony komunikat z posiedzenia BP KC PZPR. Kończył się on znamiennymi - jak się okazało - słowami. „Biuro Polityczne zaleciło rządowi podjęcie skutecznych posunięć dla złagodzenia trudności rynkowych i przeciwdziałania zjawisku nadmiernych zakupów, a także spekulacji cukrem"59. Następnego dnia prasa codzienna opublikowała komunikat rządu. Poinformowano, że zgodnie z zaleceniem BP KC PZPR oraz w porozumieniu z Centralną Radą Związków Zawodowych „w trosce o zapewnienie normalnego i sprawiedliwego zaopatrzenia w cukier wszystkich ludzi pracy i ich rodzin [Rada Ministrów] postanowiła wprowadzić na okres przejściowy sprzedaż cukru na podstawie biletów towarowych"60. Dużo miejsca poświęcono wyjaśnieniu prawa do otrzymania biletów przez określone grupy rolników. Komunikatowi towarzyszyły artykuły publicystyczne Polskiej Agencji Prasowej podkreślające konieczność i zasadność podjętej decyzji. Uspokajano - „Bilety towarowe na cukier będą wydawane w najbliższych dniach. Wszyscy ci jednak, którzy przebywają na urlopach, czasowo za granicą czy w podróży służbowej, będą mogli je odebrać po przyjeździe do miejsca zamieszkania. Chodzi też o to, abyśmy zaczęli traktować zakupy cukru jako rzecz zwykłą. Bony gwarantują przecież każdemu nabycie niezbędnej ilości tego artykułu w jakimkolwiek dniu w okresie, na który zostają wydane"61.

Ogłoszenie decyzji o wprowadzeniu kartek 12 sierpnia 1976 r., uruchomiło stosowne procedury. 14 i 15 sierpnia (sobota-niedziela) przeprowadzono remanenty. Przy okazji personel niektórych sklepów próbował ukryć część cukru ${ }^{62}$.

Szeroką dyskusję wywołało zróżnicowanie przydziałów dla ludności miejskiej i wiejskiej, zwłaszcza pozbawienie części rolników dostępu do kartek. Takie zróżnicowanie przydziałów spowodowało duże niezadowolenie. Rolnicy - słusznie zresztą - uważali, że zostali potraktowani gorzej niż pracownicy zakładów przemysłowych ${ }^{63}$. „Kpt. E. Dehmel - uzyskał

59 Posiedzenie Biura Politycznego KC PZPR, „Nowiny”, 12 VIII 1976, s. 1, 2.

${ }^{60}$ Komunikat Rady Ministrów, „Nowiny”, 13 VIII 1976, s. 1.

${ }^{61}$ Niezbędna decyzja, „Nowiny”, 13 VIII 1976, s. 1, 2.

${ }^{62}$ AAN, PIH, 1/15, „Informacja o wynikach kontroli - prawidłowości przeprowadzonych spisów remanentowych cukru (w dniach 14 i 15 sierpnia 1976 r.) oraz realizacji Uchwały nr 174 Rady Ministrów z dnia 12 sierpnia 1976 r. w sprawie sprzedaży cukru na bilety towarowe oraz sprzedaży komercyjnej cukru", k. 169.

${ }^{63}$ AIPN, 0296/101, t. 3, „Informacja o sytuacji społeczno-ekonomicznej w kraju”, 14 VIII 1976, k. 28; AIPN, 365/87, t. 1, „Informacja dot. stanu rozpoznania zagrożeń bezpieczeństwa wewnętrznego kraju w sierpniu 1976 r.”, k. 202. 
od tajnego współpracownika ps. «Irek» informację, z której wynika, że rolnicy, którzy otrzymają bilety tylko na $1 \mathrm{~kg}$ cukru na osobę, są mocno oburzeni i czują się dyskryminowani przez władzę. TW przekazujący informację słyszał wypowiedzi, że w takiej sytuacji nie będą oni realizowali żadnych dostaw do Państwa” ${ }^{64}$. „Notowane są przypadki (woj. skierniewickie) uzasadniania wysokich - często paskarskich - cen [w handlu targowiskowym] koniecznością wyrównania dysproporcji w przydziale cukru dla rolników i robotników" ${ }^{65}$. W województwie koszalińskim na wsiach „notuje się wypowiedzi o niewłaściwym przydziale biletów towarowych dla rolników, przez co część społeczeństwa jest uprzywilejowana, bowiem nie wszyscy rolnicy mogą spełniać wymagane warunki, np. kontraktować zboże lub żywy inwentarz"66.

Porucznik T. Grajczak z Komendy Miejskiej MO w Poznaniu tak relacjonował: „był świadkiem rozmowy między «straganiarzami», podczas której wyrażano niezadowolenie, że osoby niekontraktujące płodów rolnych, a zaopatrujące rynki w warzywa i kwiaty zostały w systemie rozdziału cukru pokrzywdzone"67. W Zjednoczeniu Technicznej Obsługi Rolnictwa w Poznaniu padły dość ostre, ale charakterystyczne dla ówczesnego języka propagandy słowa: „każdy jest Polakiem i ma prawo się najeść - więc różnic nie powinno być - to się ludziom nie podoba"68. Trzeba jednak pamiętać, że dla tych osób wyższa cena cukru nie była raczej problemem. W innej sytuacji znaleźli się księża. „Kurialiści gnieźnieńscy oraz księża dekanatu Śrem decyzję rządu o wprowadzeniu kartek na cukier przyjęli przychylnie. W dyskusjach podkreśla się, że rząd nie zapomniał o księżach. Mówią, że nareszcie zostali potraktowani jak robotnicy, bo dotychczas byli traktowani jak «niebieskie ptaki»”"69. „Niektórzy jezuici z Warszawy oceniają to jako ukłon w stosunku do Kościoła"70.

${ }^{64}$ AIPN Po, 06/161/2, „Informacje źródłowe, Raport dla Wojewódzkiego Stanowiska Kierowania Komendy Wojewódzkiej MO w Poznaniu, 14 VIII 1976, k. 49-50.

${ }^{65}$ AIPN, 0296/101, t. 3, „Informacja o sytuacji społeczno-ekonomicznej w kraju w dniach 14-15 bm.", 16 VIII 1976, k. 32.

${ }^{66}$ AIPN Sz, 443/50, „Meldunek 5/76 KW MO w Koszalinie do MSW”, 14 VIII 1976, k. 336.

${ }^{67}$ AIPN Po, 06/161/2, „Informacje źródłowe, Raport dla Wojewódzkiego Stanowiska Kierowania Komendy Wojewódzkiej MO w Poznaniu”, k. 13-14.

68 AIPN Po, 06/161/2, „Informacje źródłowe, Kodogram KM MO Września nr a-1438/76 z 15 sierpnia 1976 r.”, k. 97.

${ }^{69}$ AIPN Po, 06/161/2, „Informacje źródłowe, Informacja Wydziału IV KW MO w Poznaniu", 13 VIII 1976, k. 21.

70 AIPN, 0296/101, t. 3, „Informacja o sytuacji społeczno-ekonomicznej w kraju”, 14 VIII 1976, k. 28. 
Władze musiały zmierzyć się także z przygotowaniem i dystrybucją biletów towarowych. Jak oceniał znawca dokumentów reglamentacji Jan Oleński: „Bony zostały wydrukowane na papierze ze znakiem wodnym, miały piękny gilosz, nieustępujący jakością ówczesnym banknotom. Nacięcia umożliwiały dzielenie bonów na pół. [--] Zastosowano oryginalną technikę kasowania bonów na cukier polegającą na odrywaniu jednego z rogów. Zapewne z tej przyczyny następne bony miały w rogach także wydrukowane liczby określające nominał"71. Sklepy otrzymały obowiązek szczegółowego rozliczania wykorzystanych kartek naklejonych po 50 (lub $100 \mathrm{w}$ przypadku połówek biletów) na arkusze papieru. Dokumentację miały uzupełniać zlecenia od placówek kupujących cukier na podstawie zlecenia (przydziału). Po sprawdzeniu dokumentacja miała być kasowana przekreśleniem ${ }^{72}$.

Dystrybucja biletów towarowych odbywała się za pośrednictwem Narodowego Banku Polskiego, z którego oddziałów zakłady pracy pobierały potrzebne ilości dokumentów. Niepracującym (w tym rencistom i emerytom na podstawie ostatniego odcinka potwierdzającego odbiór świadczenia) kartki miały przekazywać stosowne organizacje, a przede wszystkim administracje domów mieszkalnych ${ }^{73}$. Rzemieślnikom i pracownikom handlu nieuspołecznionego - organizacje ich zrzeszające (np. cechy $)^{74}$. Rolnicy kartki na cukier otrzymywali od sołtysów lub w urzędach gmin. Akcja dystrybucji bonów towarowych rozpoczęła się już w sobotę 14 sierpnia i trwała w niedzielę 15 sierpnia. Część ADM-ów w tych dniach pracowała do późnego wieczora ${ }^{75}$. Osoby „bezprzydziałowe” mogły ubiegać się o kartki w wydziałach handlu urzędów miejskich bądź w urzędach gmin $^{76}$. W pierwszych dniach obowiązywania reglamentacji (do końca sierpnia 1976 r.) można było zrealizować tylko pół przydziału (czyli także pół kartki). We wrześniu można było realizować pozostałą częśćp7.

Operację rozdziału bonów towarowych starannie kontrolowało MSW. Nie tylko zbierano i analizowano nastroje, ale ponownie nakazano

${ }^{71}$ J. Oleński, Bilety na cukier, „Pamięć.pl” 2013, nr 7/8, s. 67.

72 AAN, MHWiU, 20/4, t. 3, „Zarządzenie nr 95 Ministra Handlu Wewnętrznego i Usług z dnia 12 sierpnia 1976 r. w sprawie wprowadzenia na okres przejściowy sprzedaży cukru na podstawie biletów towarowych”, k. 175-178.

${ }^{73}$ AIPN, 0753/35, „Lato-76, Stenogram z telekonferencji wiceministra gen. Bogusława Stachury”, 11 VIII 1976, k. 134.

74 Jeszcze o biletach towarowych, „Nowiny”, 16 VIII 1976, s. 2.

75 Bilety towarowe umożliwia normalne zaopatrywanie się w cukier - mówią ze zrozumieniem ludzie pracy, „Nowiny”, 14-15 VIII 1976, s. 3.

${ }^{76}$ Jeszcze o biletach towarowych, s. 2.

77 J. Oleński, op. cit., s. 67. 
skoszarować Zmotoryzowane Odwody MO [ZOMO]. Odwoływano się przy tym do zasad określonych przy realizacji operacji Lato-76 oraz antyspekulacyjnego zarządzenia ministerstwa spraw wewnętrznych ${ }^{78}$. Jednocześnie ruszyła operacja „BT”, polegająca na przerzuceniu do wojewódzkich oddziałów NBP bonów towarowych na cukier. Przy organizacji akcji zastosowano mechanizm sprawdzony dwa miesiące wcześniej przy okazji dystrybucji nowych cenników ${ }^{79}$. Nocą z 13 na 14 sierpnia 1976 r. do wojewódzkich komend MO w Bydgoszczy, Częstochowie, Lublinie, Kielcach, Łomży, Łodzi, Poznaniu i Wrocławiu wyruszyły transporty kartek ${ }^{80}$. Do tych komend miały zgłaszać się konwoje z okolicznych województw w celu odbierania kartek. Np. do KW MO w Poznaniu skierowano milicjantów z Gorzowa, Leszna, Piły, Szczecina i Zielonej Góry. Każdy z konwojów składał się z oficera - dowódcy, milicjanta - konwojenta, milicjanta - kierowcy. Wszyscy otrzymali nakaz posiadania broni krótkiej. Na przygotowanie i dojazd konwojów do Poznania pozostawiono jedynie 18 godzin, a rozkaz wydano o $17.15^{81}$.

Pierwsze dni obowiązywania nowych regulacji przyniosły zauważalną poprawę zaopatrzenia w cukier. Wprowadzenie kartek w praktyce spowodowało chwilowe zawieszenie sprzedaży cukru. Klienci po prostu musieli poczekać na dystrybucję kartek. „Sytuacja w sklepach spożywczych po wprowadzeniu biletów towarowych na cukier ustabilizowała się - przed sklepami kolejek nie ma, bo nie ma również w sprzedaży cukru" ${ }^{2}$. W kolejnych dniach było jednak lepiej. Cukier był dostępny zarówno w sprzedaży kartkowej, jak i komercyjnej ${ }^{83}$. Było to nie tylko zasługą reglamentacji, ale także ograniczeń w dostawach do odbiorców hurtowych. „Ze znajdujących się w magazynach hurtowych zleceń wystawionych przez Wydziały Handlu [Urzędów Wojewódzkich] wynika, że przydziały cukru dla zakładów gastronomicznych i produkcyjnych pionu

78 AIPN, 0753/35, „Lato-76, Stenogram z telekonferencji wiceministra gen. Bogusława Stachury”, 11 VIII 1976, k. 134-135. Te nadzwyczajne środki zniesiono rano 17 sierpnia. AIPN, 0753/35, „Lato-76, Szyfrogram MSW nr 707/76 z 16 sierpnia 1976 r.”, k. 141.

79 P. Sasanka, op. cit., s. 149-150.

${ }^{80}$ AIPN, 0753/35, „Lato-76, Biura Operacyjnego KG MO Szyfrogram nr 762 z 13 sierpnia 1976 r.", k. 137.

81 AIPN, 0753/35, „Lato-76, Biura Operacyjnego KG MO Szyfrogram nr 481 z 13 sierpnia 1976 r.", k. 130.

${ }^{82}$ AIPN Po, 06/161/2, „Informacje źródłowe, Informacja o sytuacji rynkowej w woj. poznańskim", 14 VIII 1976, k. 44.

83 AAN, PIH, 1/15, „Informacja o wynikach kontroli - prawidłowości przeprowadzonych spisów remanentowych cukru (w dniach 14 i 15 sierpnia 1976 r.) oraz realizacji Uchwały nr 174 Rady Ministrów z dnia 12 sierpnia 1976 r. w sprawie sprzedaży cukru na bilety towarowe oraz sprzedaży komercyjnej cukru", k. 169-170. 
prywatnego i spółdzielczego zostały od 40 do 50 proc. zmniejszone" informowano po kontroli PIH przeprowadzonej na przełomie sierpnia i września $1976 \mathrm{r}^{84}$

PIH po analizie sytuacji w 1348 palcówkach handlowych raportowała: „Kontrole przeprowadzone w sieci handlu detalicznego wskazują, że zasady sprzedaży cukru na podstawie biletów towarowych i po cenach komercyjnych były wszędzie przestrzegane. W toku kontroli stwierdzono sporadyczne, drobne uchybienia w tym zakresie, które nie mogą ważyć na ogólnie pozytywnej ocenie realizacji przez personel sklepów postanowień w sprawie sprzedaży cukru na bilety towarowe oraz po cenach komercyjnych. Do negatywnych zjawisk należy zaliczyć występujące w niektórych miejscowościach przypadki okresowych braków cukru na bilety towarowe" 85 . Dwa tygodnie po wprowadzeniu reglamentacji, cukru wciąż brakowało w 4 proc. polskich sklepów (choć występowały tu duże różnice regionalne - w Łodzi brak cukru odnotowano w 15,5 proc. sklepów) ${ }^{86}$. Miesiąc później - w 1,6 proc. skontrolowanych punktów sprzedaży.

Tak jak wspomniano, reglamentacja cukru miała być jedynie rozwiązaniem czasowym. Jednak zamiast jej zniesienia system był uszczegóławiany i rozbudowywany. Już w końcu sierpnia 1976 r. ograniczono liczbę podmiotów, którym przysługiwał cukier po niższej cenie na podstawie przydziałów ${ }^{87}$. Uszczegóławiano także system rozliczeń dokumentów uprawniających do preferencyjnych form zakupów ${ }^{88}$. Równocześnie naciskano na zakłady pracy, by przywróciły mleko jako podstawowy produkt wydawany pracownikom pracującym w uciążliwych warunkach dla zdrowia ${ }^{89}$. W poprzednich latach wiele przedsiębiorstw zamiast mleka wprowadziło cukier, co spotkało się z dużą przychylnością załóg.

${ }^{84}$ AAN, PIH, 1/15, „Informacja o wynikach prawidłowości wykonania decyzji w zakresie oszczędnego gospodarowania mięsem, cukrem i masłem”, 17 IX 1976, k. 218.

${ }^{85}$ Ibidem, k. 219-220.

${ }^{86}$ AAN, PIH, 1/15, „Informacja o wynikach kontroli stanu zaopatrzenia jednostek handlu detalicznego w wybrane artykuły żywnościowe", 3 IX 1976, k. 208-212.

87 AAN, MHWiU, 20/4, t. 3, „Zarządzenie nr 97 Ministra Handlu Wewnętrznego i Usług z dnia 27 sierpnia 1976 r. zmieniające zarządzenie w sprawie wprowadzenia na okres przejściowy sprzedaży cukru na podstawie biletów towarowych, k. 185-186.

${ }^{88}$ AAN, MHWiU, 20/4, t. 3, „Zarządzenie nr 99 Ministra Handlu Wewnętrznego i Usług z dnia 12 października 1976 r. zmieniające zarządzenie w sprawie wprowadzenia na okres przejściowy sprzedaży cukru na podstawie biletów towarowych", k. 181-182.

${ }^{89}$ AAN, PIH, 1/15, „Notatka dla Podsekretarza Stanu mgr. T. Miciaka w sprawie sprzedaży cukru dla zakładów pracy", 3 IX 1976, k. 249. 
Jeżeli wierzyć doniesieniom MSW, decyzja o wprowadzeniu biletów towarowych została dobrze przyjęta przez znaczną część społeczeństwa ${ }^{90}$. „Poinformowanie załóg niektórych zakładów pracy o decyzjach Rządu, a następnie opublikowanie komunikatu w środkach masowego przekazu - zostało przyjęte $\mathrm{w}$ całym kraju z dość powszechną aprobatą. Uważa się, że decyzje te powinny wpłynąć na uspokojenie sytuacji rynkowej oraz umożliwić sprawiedliwe zaspokojenie niezbędnych potrzeb ludności. W większości komentarzy [--] podkreśla się, że przydział $2 \mathrm{~kg}$ cukru na osobę jest wystarczający"91. Nie brakło jednak uwag, że właściwszy byłby wymiar $3 \mathrm{~kg}$. W Poznaniu opiniowano: „Tego rodzaju posunięcie oceniane jest pozytywnie, głównie ze względu na zlikwidowanie «pogoni za cukrem», jego spekulacyjnej sprzedaży i narastającego bałaganu handlowego na tym odcinku"92. Barbara Majewska z Lublina tak pisała w liście skierowanym do KC PZPR ${ }^{93}$ : „Świetnie się stało, że wreszcie uporaliśmy się z problemem cukru. [--] To nie wstyd - bony, wstyd to kolejki". W innych listach nawoływano wręcz do rozszerzenia listy reglamentowanych towarów („dziękujemy za cukier, ale zróbcie jeszcze bony na mięso, to wreszcie każdy je dostanie” ${ }^{4}$, „w podobny sposób należałoby rozwiązać problem sprzedaży mięsa i jego przetworów oraz pełnotłustego mleka” ${ }^{95}$, „niektórzy [--] chcieliby widzieć takie same rozwiązania przy zaopatrzeniu społeczeństwa w mięso i wędliny” ${ }^{6}$, „w niektórych zakładach pracy postuluje się również, aby tę formę sprzedaży rozszerzono na inne artykuły, przede wszystkim na mięso i jego przetwory"97). W województwie wrocławskim pozytywna opinia kierownictwa zakładów pracy miała źródło w przekonaniu, że reglamentacja zdejmie

90 Choć zaufania do władzy to posunięcie nie przywróciło - kolejki wciąż stały przed sklepami. AIPN, 0296/101, t. 3, „Informacja o sytuacji społeczno-ekonomicznej w kraju", 14 VIII 1976, k. 28.

91 AIPN, 0296/101, t. 3, „Informacja o sytuacji społeczno-ekonomicznej w kraju”, 13 VIII 1976, k. 24; AIPN, 0296/101, t. 3, „Informacja o sytuacji społeczno-ekonomicznej w kraju", 14 VIII 1976, k. 27.

${ }_{92}$ AIPN Po, 06/161/2, „Informacje źródłowe, Informacja sytuacyjna II”, 12 VIII 1976, k. 1 .

93 Oczywiście trzeba pamiętać, iż listy do KC PZPR nie były miarodajnym probierzem rzeczywistości.

${ }^{94}$ G. Miernik, Potoczne postrzeganie problemów gospodarczych w latach 1971-1980 w świetle listów, w: Gospodarka i społeczeństwo w czasach PRL-u (1944-1989), red. E. Kościk, T. Głowiński, Wrocław 2007, s. 390; por. też AIPN Po, 06/161/2, „Informacje źródłowe”, k. 16 nn.

95 AIPN Po, 06/161/2, „Informacje źródłowe, Informacja dot. wypowiedzi na temat nowego systemu sprzedaży cukru (Wydział III)", 13 VIII 1976, k. 16-17; por. też AIPN Po, 06/161/2, „Informacje źródłowe”, k. 16 nn.

96 AIPN Wr, 054/989, „Notatka służbowa”, 19 VIII 1976, k. 5.

97 AIPN w Łodzi, PF10/966, „Informacja sytuacyjna nr 6”, 14 VIII 1976, k. 6. 
z nich obowiązek organizowania sprzedaży cukru na terenie przedsiębiorstw $^{98}$. MSW odnotowywało liczne wyrazy „ulgi i aprobaty”, ale także opinie, że decyzja zapadła zbyt późno.

Badania socjologiczne przeprowadzone we wrześniu 1976 r. pokazały, że 71 proc. ankietowanych uznało decyzję o wprowadzeniu kartek za słuszną lub raczej słuszną, a tylko 11 proc. uważało ją za niesłuszną, 10 proc. miało wątpliwości, a 8 proc. nie miało zdania. Gdyby z badania wyłączyć rolników (których część była wyłączona z systemu) - stopień akceptacji sięgałby 77 proc. ${ }^{99}$ Nawet zakładając obawy ankietowanych przed wyrażeniem opinii niezgodnej z "linią władz”, nie można zaprzeczyć, że poziom akceptacji decyzji o reglamentacji był niewątpliwie duży i dobitnie świadczył o zmęczeniu społeczeństwa nienormalną sytuacją w handlu.

$\mathrm{Na}$ pewno na powyższe opinie wpływała też zmasowana propaganda - takie polecenie wydano wszak wraz z decyzją o wprowadzeniu kartek. Sobotnio-niedzielne wydanie rzeszowskiego dziennika PZPR „Nowiny” przynosiło całą gamę głosów pełnych zachwytów nad nowym rozwiązaniem. „Decyzję w sprawie okresowego wprowadzenia sprzedaży cukru na podstawie biletów towarowych uważam za niezbędną - mówi tkaczka z Zakładów Przemysłu Lniarskiego w Krośnie”. „Decyzja rządu przyniosła rozwiązanie, zapewnia sprawiedliwe zaopatrzenie w cukier wszystkich ludzi pracy i ich rodzin. Nie będzie też takich sytuacji, że jedni gromadzili nadmierne zapasy, a inni nie mogli zaspokoić nawet swoich bieżących potrzeb”. „W tej sytuacji wczorajszą decyzję rządu uważam za bardzo słuszną i potrzebną. Nie będziemy marnować czasu w kolejkach, a równocześnie będziemy zaopatrzeni w ten podstawowy artykuł spożywczy w zupełnie wystarczającym stopniu.” „Czekaliśmy na taką decyzję - mówi [--] elektryk z Zakładu Mechanicznego KiZPS «Siarkopol»"100. Po dwóch dniach sprzedaży cukru według nowych zasad prasa donosiła: „Do lokali handlowych wrócił spokój i porządek. Znikły kolejki utrudniające dokonanie zakupu innych artykułów"101.

Jednak byli też tacy, którzy zauważali irracjonalizm zaistniałej sytuacji i w perspektywie obniżenie powagi PRL na arenie międzynarodowej $^{102}$. „Nie brak jednak także głosów sceptycznych stwierdzających,

98 AIPN Wr, 054/989, „Informacja dotycząca sprawy «Rynek»”, 12 VIII 1976, k. 130.

${ }_{99}$ P. Sasanka, op. cit., s. 385-386.

100 Bilety towarowe umożliwia normalne zaopatrywanie się w cukier, s. 3.

101 (e), Sprzedaż cukru na nowych zasadach, „Nowiny”, 18 VIII 1976, s. 1.

102 AIPN, 0296/101, t. 3, „Informacja o sytuacji społeczno-ekonomicznej w kraju”, 13 VIII 1976, k. 25; AIPN, 0296/101, t. 3, „Informacja o sytuacji społeczno-ekonomicznej w kraju”, 14 VIII 1976, k. 28, 29; AIPN, 0296/101, t. 3, „Informacja o sytuacji społeczno-ekonomicznej w kraju w dniach 14-15 bm.", 16 VIII 1976, k. 31. 
że spodziewane wprowadzenie sprzedaży kartkowej cukru w kraju będącym potentatem $\mathrm{w}$ tej dziedzinie nie przysporzy nam sławy za granicą i będzie miało ujemny wydźwięk propagandowy. Poza tym kartki niektórzy kojarzą z okresem okupacji i pierwszych lat powojennych"103. Dwa ostatnie zdania czytający podkreślił. Opisywaną sytuację świetnie skonstatował P. Sasanka, pisząc: „Nad wszystkim dominowała jednak świadomość, zwłaszcza wśród osób pamiętających czasy okupacji, że wprowadzenie kartek 30 lat po wojnie kompromituje komunistyczny system władzy w Polsce - zapewne odegrała ona ważną rolę w postępującym załamaniu nastrojów społecznych po czerwcu 1976 r."104. Potwierdza to autor jednego z listów skierowanego w tym czasie do KC PZPR: „W 30 lat po wojnie i w kraju, w którym nigdy nie brakowało cukru, wprowadzenie kartek kompromituje Rząd”105. W Bydgoszczy TW „Hubert” donosił, iż usłyszał, że: „obecne czasy przypominają mu czasy okupacji, kiedy wszystkie artykuły żywnościowe były na kartki [--], że również chleb będzie sprzedawany na kartki"106.

Dyskusja nad decyzją o wprowadzeniu reglamentacji toczyła się także wśród publicystów. Tu jednak widać elementy zgodne z linią propagandową władz przyjętą w drugiej połowie 1976 r., np. zwalczano pomysły rozszerzenia dystrybucji kartek na inne towary. Było to kolejne zadanie mediów, po wcześniejszym przekonywaniu o słuszności decyzji wprowadzającej do obiegu kartki na cukier. Już na początku września 1976 r. Jerzy Urban w tygodniku „Polityka” w artykule Miraż bonów postulował nierozszerzanie reglamentacji na inne towary. Artykuł ten wywołał dość dużą dyskusję - do redakcji pisali zarówno zwolennicy rozszerzania reglamentacji, jak i jej przeciwnicy. Polemizował z nimi Urban, uspokajając, że w zasadzie kłopoty na rynku wewnętrznym są wynikiem niespotykanego w polskiej historii rozwoju gospodarczego i ceną, którą warto za to zapłacićcio7.

Przez lata uważano, że to właśnie olbrzymi strach władzy przed skojarzeniami wprowadzonej reglamentacji z trudnymi latami wojennymi i powojennymi powodował, iż postanowiono posługiwać się neutralnym

103 AIPN Po, 06/161/2, „Informacje źródłowe, Informacja sytuacyjna II”, 12 VIII 1976, k. 1.

104 P. Sasanka, op. cit., s. 385.

105 G. Miernik, op. cit., s. 390; por. też P. Sasanka, op. cit., s. 385.

106 AIPN w Bydgoszczy, 044/1044, „Wyciąg z informacji TW «Hubert» z 19 sierpnia 1976 r.", k. 63.

${ }^{107}$ K. Michna, Kartki na cukier. Problem publicystyczny. Wprowadzenie kartek na cukier w świetle publicystyki tygodnika „Polityka” w 1976 r., „Zeszyty Naukowe Towarzystwa Doktorantów Uniwersytetu Jagiellońskiego. Nauki Społeczne” 8, 2014, 1, s. 69-74. 
(jak się wówczas wydawało) określeniem „bilety towarowe”. Na gorąco komentował to w swoich zapiskach Michał Głowiński: „Bilety towarowe. Ten terminologiczny neologizm wprowadzono dnia 12 sierpnia - w zarządzeniu o kartkach na cukier. Normalnie w tym kontekście słowo «kartki» paść nie miało prawa. Zrezygnowano także z bardziej w polszczyźnie oswojonych «bonów» czy «bonów towarowych». Manipulowanie językiem polega nie tylko na sugerowaniu dogodnych dla władz konotacji, polega także na eliminowaniu tych wyrażeń, które są dla niej nieprzyjemne. «Kartki» kojarzą się z okupacją, z nędzą, z niedojadaniem, a racjonowanie cukru interpretuje się jako kolejne zwycięstwo klasy robotniczej. Nie pojawia się zresztą także słowo «racjonowanie». Potocznie jednak wszyscy mówią o kartkach. Przyzwyczajeń językowych nie można wyeliminować za pomocą jednego administracyjnego zarządzenia" ${ }^{108}$. Bardzo szybko termin „bilety towarowe” odnotowała w paryskiej „Kulturze” Zofia Hertz. W humorystycznej rubryce „Humor krajowy” przywołała polityczny kawał nadesłany z kraju: „Żeby nie nasuwać nieprzyjemnych skojarzeń, kartki na cukier nazwano «biletami towarowymi». W związku z tym: niektórzy dostają cukier na bilety, a inni na gapę, a o Gierku mówi się: główny bileter"109.

Powyższa interpretacja nie jest jednak prawdziwa. 12 sierpnia, gdy o decyzji BP KC PZPR rozmawiano na posiedzeniu rządu, Jaroszewicz pytał, dlaczego nie została użyta nazwa kartki lub bony. Pyka wówczas wyjaśniał: „Można było również przyjać albo bony, albo bilety, albo jeszcze jakieś inne nazwy, kartki również. Musieliśmy wydrukować bony, bilety towarowe w ilości $120 \mathrm{mln}$ sztuk. Drukujemy w czterech drukarniach. Ponieważ druk rozpoczął się trzy tygodnie wcześniej, trzeba było napisać bilety, w obawie, żeby nie stworzyć dodatkowych komplikacji rynkowych ${ }^{110}$. W związku z tym przyjęto nazwę bilety. Czy bilet będzie zmieniony za dwa tygodnie, za miesiąc na bon towarowy, trudno dziś

108 M. Głowiński, Peereliada. Komentarze do słów 1976-1981, Warszawa 1993, s. 7.

109 Z. Hertz, Humor krajowy, „Kultura” 1976, nr 10, s. 154. Żartów na temat wprowadzonych kartek było zresztą więcej. W Oławie MO raportowała: „wśród społeczeństwa miasta Oławy krąży wiele anegdot i piosenek krytykujących posunięcia rządu PRL”. M.in. zanotowano kawały: „Aktualnie obowiązujący model picia herbaty to bez łyżeczki”, „Wzór picia herbaty po syberyjsku: rodzina w komplecie przy stole, przed każdym szklanka herbaty, a pośrodku nad sufitem zawieszona kostka cukru - słodzenie herbaty metodą wizualną”, AIPN Wr, 054/989, „Notatka służbowa”, 18 VIII 1976, k. 23; AIPN Wr, 054/989, „Notatka służbowa”, 19 VIII 1976, k. 5; AIPN Wr, 054/989, „Notatka służbowa”, 20 VIII 1976, k. 8.

110 Warto pamiętać, że na kartkach oprócz napisu „Bilet Towarowy”, dat emisji i cyfr $(1$ lub 0,5) nie było żadnych oznaczeń (np. cukier czy kg). 
powiedzieć. Sądzę, że albo bilet, albo bon w tym wydaniu, które ma dość ciekawą szatę graficzną"111.

Wprowadzenie kartek część Polaków odczytała jako swoistego rodzaju karę dla społeczeństwa, które w czerwcu 1976 r. oparło się podwyżkom ${ }^{112}$. „Ppor. M. Fliskowski - od OZ [osobowego źródła] „K” uzyskał informację mówiącą o nieprzychylnych komentarzach na temat decyzji Rządu o wprowadzeniu biletów towarowych. Podstawą tych komentarzy jest fakt uwidocznienia na biletach towarowych daty «25 lipca 1976 r.», natomiast decyzja o wprowadzeniu biletów towarowych na sprzedaż cukru pochodzi z dnia 11 sierpnia 1976 r. W związku z tym mówi się, że zła sytuacja w zakresie zaopatrzenia ludności w niektóre artykuły była wywołana sztucznie i celowo. Mówi się także, że wcześniejsze przygotowanie bonów towarowych jeszcze przed oficjalną decyzją Rządu miało związek z chęcią wprowadzenia ich jako środka regulującego zaopatrzenie ludności w mięso"113. Rządzącym chodziło jednak o coś innego. Po pierwsze trzeba było w trybie natychmiastowym uspokoić napięte brakami nastroje społeczne. Po drugie ograniczono spożycie cukru, aby uzyskane w ten sposób nadwyżki kierować na eksport ${ }^{114}$. Po trzecie liczono, iż utrudniony dostęp do cukru ograniczy bimbrownictwo ${ }^{115}$ i zwiększy zyski państwowego monopolu. Tańszy cukier powodował, że pędzenie bimbru było bardzo opłacalne. Zdawano sobie sprawę, że utrzymanie niskiej ceny cukru i podwyższenie ceny alkoholu zaowocuje nielegalną produkcją tego drugiego. W tym czasie butelka bimbru była przynajmniej o połowę tańsza niż alkoholu sklepowego. Tymczasem wpływy do budżetu państwa ze sprzedaży alkoholu w połowie lat siedemdziesiątych XX w. stanowiły ok. 12,5-14 proc. dochodów budżetu państwa ${ }^{116}$. Przewidziana kartkowa norma praktycznie uniemożliwiała skorzystanie z niej bez konsekwencji dla pozostałej części konsumpcji1" ${ }^{117}$. Podjęta decyzja

111 AAN, URM, 5.3/91, „Zapis przebiegu obrad posiedzenia Rady Ministrów w dniu 12 sierpnia 1976 r.”, k. 263.

112 M.F. Rakowski, Dzienniki polityczne 1976-1978, Warszawa 2002, s. 108.

113 AIPN Po, 06/161/2, „Informacje źródłowe, Raport dla Wojewódzkiego Stanowiska Kierowania Komendy Wojewódzkiej MO w Poznaniu”, 16 VIII 1976 r., k. 104.

${ }^{114}$ Ministerstwo Handlu Zagranicznego w lipcu alarmowało, że nie jest w stanie wywiązać się z podjętych zobowiązań. AAN, URM, 94/63, „Zapis przebiegu obrad na posiedzeniu Prezydium Rady Ministrów w dniu 24 lipca 1976 r.”, k. 295.

${ }^{115}$ K. Kosiński, Historia pijaństwa w czasach PRL. Polityka - obyczaje - szara strefa patologie, Warszawa 2008, s. 342, 542.

116 Ibidem, s. 48.

117 Najbardziej popularny, „grunwaldzki” przepis na zacier standardowo przewidywał bowiem wykorzystanie przynajmniej kilograma cukru (1 kg cukru, 41 wody, 10 dag drożdży). 
miała także charakter drenażowy - ludzie de facto zostali zmuszeni do płacenia za cukier wyższej ceny. Oficjalnie jednak winą za konieczność wprowadzenia reglamentacji obarczono spekulantów i „chomikarzy”118. Wszystko to nie zmienia jednak faktu, że wprowadzenie kartek na cukier było porażką władzy. 4 września 1976 r. w Wytwórni Sprzętu Komunikacyjnego „Mielec” Gierek mówił: „Jak chodzi o cukier, to przecież myśmy zmuszeni byli do wprowadzenia biletów. My traktujemy to jako rozwiązanie konieczne, a nie delektujemy się tym"119. Trudno się z tym nie zgodzić.

Jak zostało wspomniane na początku, reglamentacja cukru ${ }^{120}$ była wprowadzona - przynajmniej deklaratywnie - jako rozwiązanie czasowe. Organizacja systemu wskazuje na to, że decyzję o jej utrzymaniu po raz pierwszy podjęto jesienią 1976 r. Jeszcze w połowie września powtórzono bowiem operację rozwożenia kartek, wykorzystując konwoje milicyjne ${ }^{121}$. W następnym miesiącu zmieniono wygląd kartek. J. Oleński pisał: „Od października rozpoczęto sprzedaż cukru na nowe «bilety». Były one wykonane równie starannie jak poprzednie, a każdy z nich składał się z dwóch bonów: na pierwszą i na drugą połowę miesiąca o nominałach 1 lub 0,5 kg"122. Zapewne decyzji o utrzymaniu reglamentacji sprzyjały niepokojące informacje o plonach buraków cukrowych w 1976 r., które zapowiadały się niższe niż przed rokiem ${ }^{123}$.

We wspomnianym wyżej kształcie kartki funkcjonowały do końca lutego 1977 r. Wówczas po raz kolejny zmieniono ich wygląd - odtąd przypominały one znaczki pocztowe (o nominale jednego, dwóch i pół kilograma). Jednocześnie z ich wprowadzeniem ułatwiono zakupy można było już realizować przydziały jednorazowo w całości ${ }^{124}$.

118 K. Cegieła, Kartki na szczęście. Reglamentowanie dóbr w Polsce Ludowej, „Mówią Wieki" 2002, nr 4, s. 14.

119 Archiwum TVP: Zagadki tamtych lat, odc. 1.: Dlaczego w PRL brakowało cukru?, scen. M. Matys, TVP 2009.

${ }^{120}$ Cukier do końca lat siedemdziesiątych był jedynym artykułem sprzedawanym w powszechnej reglamentacji. Władze częściej posługiwały się centralnym rozdzielnictwem towarów za pomocą rozdzielników wojewódzkich. W ten sposób preferowano niektóre regiony i miasta (przemysłowe) kosztem innych (terenów rolniczych). Por. też: K. Hagemejer, Ekonomiczne i społeczne funkcje reglamentacji, w: Umowa o kartki, red. J. Kurczewski, Warszawa 2004, s. 51.

121 AIPN, 0753/35, „Lato-76, Szyfrogram Biura Operacyjnego KG MO nr 4016 z 13 września 1976 r.", k. 145.

${ }^{122}$ J. Oleński, op. cit., s. 67.

123 AAN, URM, 5.3/92, „Zapis przebiegu obrad na posiedzeniu Rady Ministrów w dniu 15 października 1976 r.”, k. 252; AAN, URM, 2382/23, „Zapis magnetofonowy spotkania członków Rady Ministrów w dniu 19 listopada 1976 r.”, k. 729-731,

${ }^{124}$ J. Oleński, op. cit., s. 67. 
Warto na decyzję o wprowadzeniu kartek na cukier spojrzeć także z perspektywy zaopatrzenia rynku w mięso. Władza była w skrajnie trudnym położeniu - brak cukru nakręcał panikę rynkową także na inne towary. Rząd wiedział już także, że ilość dostarczanego mięsa do sklepów w sierpniu będzie znacznie mniejsza niż zapotrzebowanie ${ }^{125}$. Panika rynkowa taką sytuację jeszcze bardziej pogłębiłaby. Mimo to starannie dbano, by nie dopuścić do rozszerzenia reglamentacji na kolejne towary ${ }^{126}$. Pozostawiono kartki na cukier.

W maju 1980 r. wprowadzono możliwość otrzymania ekwiwalentu za niewykorzystane kartki w wysokości 15,50 zł za niezrealizowaną normę kilogramową ${ }^{127}$. Ta decyzja była kolejnym ciosem w szarą strefę. Niewykorzystane kartki nie musiały już trafiać do obrotu wtórnego, w tym do bimbrownictwa. Jednocześnie można przypuszczać, że w ten sposób rozpoczęto proces odchodzenia od sprzedaży na kartki. Kryzys polityczny lata 1980 r. i jego konsekwencje dla gospodarki proces ten przerwały.

Generalnych zmian w reglamentacji cukru dokonano w lutym $1981 \mathrm{r}$. W uchwale Rady Ministrów zapisano: „W związku z nieurodzajem buraków cukrowych w 1980 r. i dużym spadkiem produkcji cukru Rada Ministrów uchwala, co następuje: wprowadza się zmianę norm sprzedaży cukru na okres przejściowy od dnia 1 marca 1981 r. do dnia 31 października $1981 \mathrm{r}$. na zasadach określonych w uchwale"128. Od 1 marca przydziały cukru otrzymali wszyscy mieszkańcy Polski - także dotychczas wyłączeni z systemu rolnicy. Wyjątkiem były jedynie osoby, którym państwo zapewniało całodzienne wyżywienie - np. żołnierze służby zasadniczej. Prawo do kartek na cukier otrzymali także pracujący w Polsce cudzoziemcy (z wyjątkiem pracowników placówek dyplomatycznych). Zmniejszono za to przysługujące normy. Norma C-1 (1,5 kg miesięcznie) przysługiwała dzieciom i młodzieży do lat 18 , kobietom w ciąży (od 5 miesiąca życia) i matkom karmiącym. Norma C-2 (1 kg miesięcznie) przynależna była

125 Warto przypomnieć, że BP KC PZPR wydało komunikat zapowiadający podwyżkę cen mięsa jeszcze w 1976 r. AAN, URM, 94/63, „Stenogram posiedzenia Rady Ministrów w dniu 13 lipca 1976 r.”, k. 219-220.

126 Szerzej: A. Zawistowski, Wołanie o kartki. Reglamentacja jako pożądane przez społeczeństwo rozwiązanie problemów z równowaga w handlu wewnętrznym w latach 1976-1980, w: PRL na pochylni 1975-1980, Rzeszów 2017 (w druku).

127 Uchwała nr 42 Rady Ministrów z 10 maja 1980 r. w sprawie zasad sprzedaży cukru dla ludności, „Monitor Polski” 1980, nr 14, poz. 64; Zarządzenie Ministra Finansów z dnia 26 maja 1980 r. w sprawie trybu wypłacania przez uspołecznione zakłady pracy ekwiwalentu pieniężnego za bilety towarowe na cukier, „Monitor Polski” 1980, nr 14, poz. 65.

128 Uchwała nr 37 Rady Ministrów z dnia 20 lutego 1981 r. w sprawie zmiany norm zaopatrzenia ludności w cukier, „Monitor Polski” 1981, nr 6, poz. 48. 
pozostałej ludności ${ }^{129}$. Od tego momentu cukier sprzedawano już tylko na kartki, likwidacji uległ handel „komercyjny”. Symbolicznie zniknęły wówczas też „,bilety towarowe”, które zastąpiły „karty zaopatrzenia”"130. Zmiany te były efektem kolejnego „cukrowego” szturmu na sklepy. Od 1 października 1981 r. podwyższono przyznane normy, odpowiednio: C-1 - $2 \mathrm{~kg}$ miesięcznie i C-2 $-1,5 \mathrm{~kg}$ miesięcznie ${ }^{131}$. Wprowadzony jesienią $1981 \mathrm{r}$. system znowu miał mieć charakter jedynie czasowy (tak jak wszystkie poprzednie) - tym razem czas jego obowiązywania określono na rok.

Gwałtownie postępujące załamanie rynku artykułów żywnościowych w 1981 r. zweryfikowało jednak podjęte zaledwie kilka tygodni wcześniej decyzje. Już w grudniu 1981 r. zdecydowano się na całościowe uregulowanie powstającego przez cały rok systemu reglamentacji. Włączono do niego także zasady sprzedaży cukru. Trafił on wówczas do wspólnych dla wielu towarów norm P-I (dzieci w wieku od 1 roku do 18 lat), P-III (kobiety ciężarne od 17 tygodnia ciąży oraz matki dzieci, którym przysługiwały kartki „0”), 0 (dzieci w wieku od 0 do 11 miesięcy i 29 dni, norma $2 \mathrm{~kg}$ miesięcznie) oraz P-II (osoby powyżej 18 roku życia, $1,5 \mathrm{~kg}$ miesięcznie $)^{132}$. Tak więc od stycznia 1982 r. kartki na cukier stały się elementem szerokiego systemu reglamentacji. Jego „cukrową” część zniesiono 1 listopada $1985 \mathrm{rr}^{133}$

Wydaje się, że wprowadzenie w sierpniu 1976 r. kartek na cukier miało cel zbliżony do klasycznego modelu reglamentacji, spotykanego w wielu krajach, także o gospodarce rynkowej. Wyjątkowe jest źródło zachwiania równowagi na rynku artykułów żywnościowych - przede wszystkim cukru, choć braki innych artykułów wpływały na nakręcanie

129 Ibidem.

130 Nazwy dokumentów uprawniających do zakupów, a także ich kształt i forma w kolejnych miesiącach wielokrotnie się zmieniały. Por.: J. Oleński, Ogólnopolskie kartki zaopatrzenia z lat 1976-1989, Warszawa 2010, s. 18-37.

131 Uchwała nr 206 Rady Ministrów z dnia 25 września 1981 r. w sprawie reglamentowanej sprzedaży cukru dla ludności, „Monitor Polski” 1981, nr 26, poz. 227.

132 Uchwała nr 291 Rady Ministrów z dnia 12 grudnia 1981 r. w sprawie reglamentowanej sprzedaży towarów, „Monitor Polski” 1981, nr 33, poz. 291.

133 Uchwała nr 173 Rady Ministrów z dnia 28 października 1985 r. w sprawie zniesienia reglamentowanej sprzedaży niektórych towarów, „Monitor Polski” 1985, nr 31, poz. 211. Warto zauważyć, że w tym samym czasie zaostrzono znacznie kary za bimbrownictwo: za nielegalną produkcję groziło nawet bezwzględne więzienie. Zniesienie reglamentacji cukru było - jak publicznie zapowiadał wówczas premier Zbigniew Messner - próbą generalną przed zniesieniem reglamentacji mięsa. Gdy latem 1989 r. zlikwidowano ostatni bastion reglamentacji - kartki na mięso i wprowadzano ceny rynkowe na żywność, cukier znowu zniknął ze sklepów, Dziennik Telewizyjny z 17 sierpnia 1989 r. 
się rynkowej paniki cukrowej. Nie był nim konflikt zbrojny czy inne nadzwyczajne wydarzenia, ale wadliwa polityka gospodarcza. „Bilety towarowe" wprowadzono wbrew oczekiwaniom (a paradoksalnie jednocześnie także pod presją) społeczeństwa. Decydując się na kartki, władze rzeczywiście chciały zapewnić dostęp do cukru na podstawowym poziomie $^{134}$ dla szerokich grup społecznych. Tak jak w nadzwyczajnych sytuacjach - miało to zapewnić również względny społeczny spokój. Jednocześnie posłużono się tym narzędziem, próbując zapanować nad popytem na cukier ze strony osób uznanych (nie zawsze słusznie) za tzw. spekulantów. Przy okazji - używano cukru także jako narzędzia nacisku na rolników opierających się państwowemu systemowi skupu artykułów rolnych. Inaczej jednak niż w przypadku standardowych rozwiązań, tym razem reglamentacja nie doprowadziła do przywrócenia równowagi, ale stała się jedynie drogą do dalszego rozwinięcia systemu reglamentacji. Była forpocztą systemu, który zapanował w Polsce w latach 1981-1989.

\section{Streszczenie}

W XX w. na ziemiach polskich można wyróżnić cztery okresy reglamentacji artykułów pierwszej potrzeby: 1915-1921 (czyli okres I wojny światowej i wojny polsko-bolszewickiej), 1939-1949 (okres II wojny światowej i lata powojenne), 1951-1953 (szczyt stalinizmu) oraz 1976-1989 (czas załamania się gospodarki komunistycznej i lata powszechnego braku towarów w sklepach). Ostatni okres reglamentacji rozpoczęło wprowadzenie w sierpniu 1976 r. racjonowania cukru. Władze sięgnęły po to narzędzie w momencie, gdy zostały zmuszone do wycofania się z podwyżki cen, co zaowocowało paniką sklepową. Kartki na cukier wprowadzono, jak zapowiadano, jedynie na okres przejściowy. Pomogło to opanować sytuację na rynku, jednak przez lata nie udało się z reglamentacji zrezygnować. Kartki na cukier stały się symbolem upadku peerelowskiej gospodarki, a jednocześnie rozwiązaniem, na które powoływano się jako na modelowe rozwiązanie kłopotów $\mathrm{z}$ aprowizacją. Między innymi dlatego na początku lat osiemdziesiątych wzorem kartek na cukier zaczęto wprowadzać reglamentację kolejnych artykułów pierwszej potrzeby. Z końcem 1981 r. reglamentacja cukru stała się częścią szerokiego mechanizmu kartkowego.

134 Jak wskazują dane statystyczne, spożycie cukru przez mieszkańca Polski do 1981 r. nie przekroczyło poziomu z 1976 r. (43,9 kg). Por.: Rocznik Statystyczny 1978, s. 68; Rocznik Statystyczny 1979, Warszawa 1979, s. 81; Rocznik Statystyczny 1981, Warszawa 1981, s. 123; Rocznik Statystyczny 1982, Warszawa 1982, s. 123. 


\section{"Ration cards are not shameful but queues are". Sugar Rationing in the Polish People's Republic in 1976-1981}

The twentieth century witnessed four periods of food rationing in Polish lands: 1915-1921 (First World War and the Polish-Bolshevik War), 1939-1945 (Second World War and post-war years), 1951-1953 (the peak of Stalinism), and 1976-1989 (the breakdown of the communist economy and a long-term general shortage of commodities). The last period of rationing was inaugurated in August 1976 by sugar rations. The authorities resorted to this instrument at a moment when they were compelled to withdraw their price rise policy, which resulted in panic. It was announced that sugar ration cards had been introduced only for a temporary period. This step made it possible to control the situation on the market but for years to come it proved impossible to abandon rationing. Sugar rationing became a symbol of the economic decline of the Polish People's Republic and, at the same time, a solution evoked as an exemplary answer to problems with food supplies. At the beginning of the 1980s it was one of the models for the introduction of rationing essentials. At the end of 1981 sugar rationing became part of a broad rationing mechanism in force until the fall of communism.

Translated by Aleksandra Rodzińska-Chojnowska

\section{Bibliografia}

„Bilety towarowe umożliwią normalne zaopatrywanie się w cukier - mówią ze zrozumieniem ludzie pracy". Nowiny, 14-15.08.1976.

Cegieła, Katarzyna. „Kartki na szczęście. Reglamentowanie dóbr w Polsce Ludowej”. Mówią Wieki, nr 4 (2002): 23-29.

(e). „Sprzedaż cukru na nowych zasadach”. Nowiny, 18.08.1976.

Głowiński, Michał. Peereliada, Komentarze do słów 1976-1981. Warszawa: PIW, 1993.

Hertz, Zofia. „Humor krajowy”. Kultura, nr 10 (1976): 154.

Hagemejer, Krzysztof. „Ekonomiczne i społeczne funkcje reglamentacji”. W Umowa o kartki, red. Jacek Kurczewski, 39-58. Warszawa: Trio, 2004.

„Jeszcze o biletach towarowych”. Nowiny, 16.08.1976.

Kisielewski, Stefan. Dzienniki. Warszawa: Iskry, 2001.

„Komunikat Rady Ministrów”. Nowiny, 13.08.1976.

Kosiński, Krzysztof. Historia pijaństwa w czasach PRL. Polityka - obyczaje - szara strefa - patologie. Warszawa: Neriton; IH PAN, 2008.

Michna, Kacper. „Kartki na cukier. Problem publicystyczny. Wprowadzenie kartek na cukier w świetle publicystyki tygodnika «Polityka» w 1976 r.". Zeszyty Naukowe Towarzystwa Doktorantów Uniwersytetu Jagiellońskiego. Nauki Społeczne 8 (2014): 61-77.

Miernik, Grzegorz. „Potoczne postrzeganie problemów gospodarczych w latach 1971-1980 w świetle listów:. W Gospodarka i społeczeństwo w czasach PRL-u (19441989), red. Elżbieta Kościk, Tomasz Głowiński, 384-407. Wrocław: GAJT, 2007. 
„Niezbędna decyzja”. Nowiny, 13.08.1976.

Oleński, Jan. „Bilety na cukier”. Pamięć.pl, nr 7/8 (16/17) (2013): 66-67.

Oleński, Jan. Ogólnopolskie kartki zaopatrzenia z lat 1976-1989. Warszawa: WCN, 2010. „Posiedzenie Biura Politycznego KC PZPR”. Nowiny, 12.08.1976.

„Przemówienie prezesa Rady Ministrów Piotra Jaroszewicza na posiedzeniu Sejmu”. Nowiny, 25.06.1976.

Rakowski, Mieczysław F. Dzienniki polityczne 1976-1978. Warszawa: Iskry, 2002.

Rocznik Statystyczny 1978. Warszawa: GUS, 1978.

Rocznik Statystyczny 1979. Warszawa: GUS, 1979.

Rocznik Statystyczny 1981. Warszawa: GUS, 1981.

Rocznik Statystyczny 1982. Warszawa: GUS, 1982.

Sasanka, Paweł. Czerwiec 1976. Geneza - przebieg - konsekwencje. Warszawa: IPN, 2006.

Zawistowski, Andrzej. „Kartki na wojnę, której nie było. Planowany mechanizm reglamentacji artykułów pierwszego zapotrzebowania w PRL w wypadku sytuacji nadzwyczajnej". Dzieje Najnowsze 48, nr 1 (2016): 67-82.

Zawistowski, Andrzej. „Wołanie o kartki. Reglamentacja jako pożądane przez społeczeństwo rozwiązanie problemów z równowagą $\mathrm{w}$ handlu wewnętrznym w latach 1976-1980". W PRL na pochylni 1975-1980. Rzeszów: IPN; PWSW, 2017 (w druku).

Biogram: dr Andrzej Zawistowski - Katedra Historii Gospodarczej i Społecznej Szkoły Głównej Handlowej w Warszawie oraz Biuro Badań Historycznych Instytutu Pamięci Narodowej, specjalizuje się w historii gospodarczo-społecznej PRL, andrzej.zawistowski@sgh.waw.pl. 